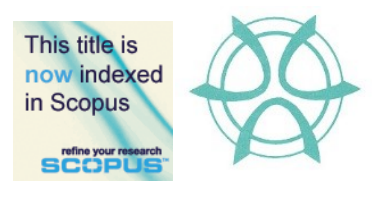

\title{
THE METHODOLOGICAL STRUCTURE FOR LEGAL RESEARCH: A PERSPECTIVE FROM THE MALAYSIAN LAND LAW AND ISLAMIC LAW
}

\author{
Noor Azimah Ghazali ${ }^{1}$, Ibrahim Sipan ${ }^{2}$, Farah Nadia Abas $^{3} \&$ Ahmad Che \\ Yaacob $^{4}$ \\ ${ }^{1,2,3}$ Center of Real Estate Studies, (CRES UTM), \\ Faculty of Built Environment and Surveying \\ ${ }^{4}$ Faculty of Islamic Civilization, \\ UNIVERSITI TEKNOLOGI MALAYSIA
}

\begin{abstract}
A legal research shall be secured with the idea to facilitate a future change; either in the law itself or in the manner of its administration from the production of 'pure' academic knowledge which is concerned legal doctrines. Therefore, this paper purpose is to propose a methodological structure for legal research within perspective Malaysian Land Law and Islamic Law to establish a regulation or amendment in the existing foundation. This paper adopts method of content analysis to understanding on the underlying reasons through expert opinions on the legal issues. The finding of this research revealed that a legal methodological framework is easily simplified in form of system theory approach. This type of methodological structure is common amongst the legal researchers, lawyers and legal scholars who embrace Pure and Applied Legal Research. The methodological structure for legal research in form of system theory shall make a better regulation proposal in the perspective of Malaysian Land Law and Islamic Law. By adopt this methodological structure; researchers shall propose new regulation or amendments as legal researchers, lawyers and legal scholars.
\end{abstract}

Keywords: framework, legal, research, land, methodology

\footnotetext{
${ }^{1}$ Corresponding Author. Email: azimahice@gmail.com
} 
N.A. Ghazali, I. Sipan \& F.N. Abas

The Methodological Structure for Legal Research: A Perspective from the Malaysian Land Law and Islamic Law

\section{INTRODUCTION}

"Methodology" implies more than the methods used to collect data. It is often necessary to include a consideration of the concepts and theories which underlie the methods (Wyse, 2011; Humanities, 2017). Methods of research can be divided into qualitative and quantitative research. Qualitative research primarily deals with exploratory research, used to investigate reasons, opinions and motivations that provides insights into the problem or helps to develop ideas or hypotheses for potential quantitative research (Tobi, 2013; Polit, Beck, and Hungler, 2001). The sample size is typically small, and the respondents are selected only to fulfil a given quota (Marshal, 1996). On the other hand, quantitative research is quantifying the problem by generating numerical data into useable statistics to quantify attitudes, opinions, behaviours, and other defined variables - and generalize results from a larger sample population (Miles and Huberman, 1994; Travers, 2005; Baur, 1965).

Through the legal doctrine and law studies, most of the methodology implies is system theory. There are number of research studies works using system theory such as Sarkawi, Ibrahim, \& Abdullah, (2008), Ismail (2017) and Husain, (2014) who studies in Muslim personal law, an exposition, all India Personal Law Board in camp office of India and Esmaeili, (2010) who studies the relationship between the waqf institution in Islamic law and the rule of law in the Middle East. Researchers who adopt system theory approach in Malaysian Land Law and Islamic Legal Research are: Afendi and Sayuti, (2012) and Latip et.al., (2020) who study on the implication of legislation in waqf land registration from land acquisition aspect, while Omar, (2013) study on issues on waqf land administration in NLC and land office of Negeri Sembilan and other law in interrelated hierarchy. However, the framework is not clearly visualised. Therefore, this research is highlighting the approach to study the variety of legal doctrines involve in Islamic Law and Malaysian Land Law.

\section{RESEARCH BACKGROUND}

This paper proposes a research using legal doctrines in conducting the investigation. The legal doctrines and investigation are visualized in the form of system theory frame. The approach of system theory was firstly developed in the 19th century by Marx and Darwin and used by L. von Bertalanffy a biologist who investigated the principles common to all complex entities, and the (usually mathematical) models that used to describe them (Twente, 1960).

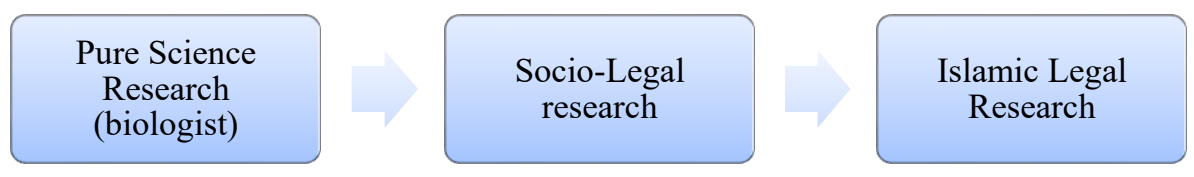

Figure 1: System Theory expansion 
In the modern world, the system theory is expanded from the world of Pure Science Research (biologist) to the Socio-Legal research and further to the Islamic Legal Research which is accurately suitable to this research within the perspective of the Islamic Law and Malaysian Land Law. Based on Twente, (1960) a system can be said to consist of four things which are:

i. Input in the form of elements or variables which is applied as attributes of relationships among its objects and systems exist in a feature the continual stages as Input

ii. Throughput (processing), and

iii. Outputs, which demonstrate the concept of which it uses to interact dynamically with its environment.

iv. Openness, interact with its environment and receive information.

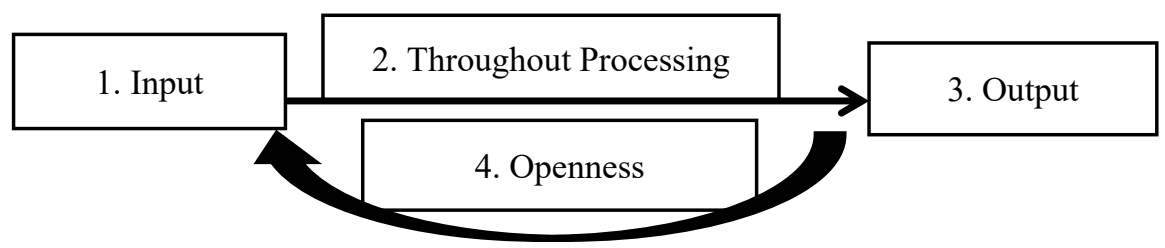

Figure 2: System Theory Holistic Approach

A system theory approach is a holistic approach, in which an entity is dealt with as a whole system that consists of a number of sub-systems (Twente, 1960). There are a number of system features that govern the analysis of a system into its subsystem components, and also define how these sub-systems interact with each other and the outside environment (Kumar, 2019; Auda, 2008). As the current research has evolved, the system theory approach is expanding to system theory of Islamic Legal Research as in Figure 3 (Auda, 2008). The system theory of Islamic Legal Research has proposed features that consist of:

i. Cognitive nature of the system - is based on the construction of jurists cognitive faculty

ii. Wholeness - is a system theory views every cause-and-effect relation as one part of a whole picture

iii. Openness - is related to ijtihad (new judicial reasoning) or open to the new environment or flexibility to today's changing circumstances

iv. Interrelated hierarchy based on categorization based on feature similarity and mental concept by practical fiqhi implementation

v. Multidimensionality - is Contradictory of Dichotomies, Binary classification in the sense of realism and flexibility in the Islamic Law lead to conciliation between evidence 
N.A. Ghazali, I. Sipan \& F.N. Abas

The Methodological Structure for Legal Research: A Perspective from the Malaysian Land Law and Islamic Law

vi. Purposefulness - is a fulfilment of society or in Islamic law it is referred as maqasid al-shariah. Maqasid of the Islamic Law are the objective/purposes behind Islamic ruling to people's interests (masalih).

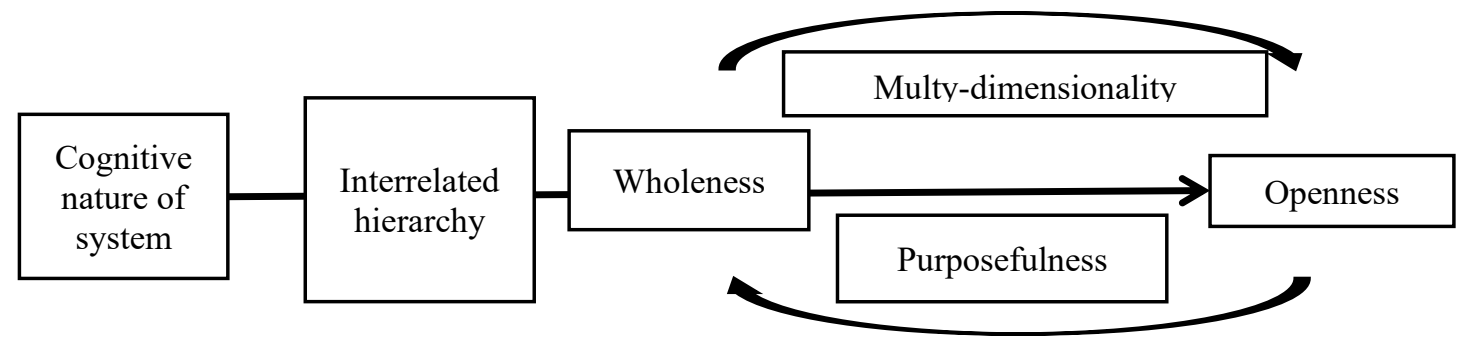

Figure 3: System Theory of Islamic Legal Research Source: Auda, (2008).

Another approach is the open texture of rules which is a process of legal reasoning. By using this approach, society would have no need for lawyers, and still less for legal scholarship. However, in order to manipulate the rules, one has to look into the rules of interpretation or rules of construction of the rules because some statutes appear ambiguous and the enacting legislature does not consider the exact situation. Changing the circumstances might be required so that the legislature did not foresee (Clark and Connolly, 2006). There are rules of statutory interpretation used to find the meaning of the language used in an Act which brought it into effect (Pacific, 2003; University, 2014). It is examined in the based on Table 1:

Table 1: Rules to Interpret Law

Source: (Knight, 2008; Pacific, 2003; University, 2014; Clark, 2006).

\begin{tabular}{cll} 
No. & Based & \multicolumn{1}{c}{ Rules to Interpret Law } \\
\hline 1 & $\begin{array}{c}\text { Words } \\
\text { Meaning }\end{array}$ & $\begin{array}{l}\text {-Literal Rule, Golden Rule, Preambles and Purpose } \\
\text { Clauses, Rule to Avoid Surplus age }\end{array}$ \\
\hline 2 & History & $\begin{array}{l}\text {-Mischief Rule, Legislative History, The Whole Act Rule, } \\
\text { Noscitur a Sociis ("it is known from its associates")-Role of } \\
\text { Analogy }\end{array}$ \\
& & $\begin{array}{l}\text {-The Problem of Casus Omissus and the Ratio Legis, } \\
\text { Canons of Construction }\end{array}$ \\
\hline 3 & Purpose &
\end{tabular}

Rules are based on words must be given their ordinary, literal, grammatical meaning, day to day meaning words it uses the language of the ordinary citizen. There is a choice of meanings as a presumption that a meaning which produces an absurd. Which certain term or phrase is used multiple times throughout a statute, that term or phrase should be interpreted in a consistent manner. Many statutes begin with a preamble or a purpose clause which could help the researcher to understand the purpose of the Act. Some rules are based on history 
which requires looking to what the law was before the statute was passed in order to discover what gap or mischief the statute was intended to cover. The court is then required to interpret the statute in such a way to ensure that the gap is covered. What a statute's history might suggest about the meaning of a word or phrase. This method is involving the method of the legal reasoning of a general rule to a specific case to another specific case.

Finally, there are rules based on purpose where the judges have to establish what the purpose is of the Act and should promote that purpose. Certain techniques of statutory construction have been used so often that they have become "formalized" into "canons." Unlike the tools provided in this handout, the canons are not particularly useful for discerning the meaning of a statute. In the end, the judge or researcher may use the method of open texture to manipulate the rules as long as it is following the interpretation and construction rules. The advantage of this method is the researcher may produce an efficient legal structure by the flexibility to manipulate the rules.

\section{METHODOLOGY}

This research is to study both communication and interaction between Islamic Law and Malaysian Land Law to formulate the methodology structure of legal research. The communication within the Islamic Law is to answer the concept of maqasid syariah in research. And the communication of the Federal Constitution, National Land Code, State Enactment and law pertaining land administration, will answer how the substantive law governing systems in Malaysia. All of the communication in law and legislation is analyzed using the literature collection by using the method of content analysis. In the content, the analysis contains several categories such as:

i. Syllogism-The method of syllogism comprised three items to formulate a rule known as the major premise, the minor premise and the conclusion, (Farrar, 1997. p. 9, 30; Knight and Ruddox, 2008)

a. Major premise- identifies a general rule of law that requires a specified legal outcome when particular facts are present in a situation.

b. Minor premise- describes a particular factual situation including the current situation

c. Conclusion- states whether the rule in the major premise applied to the facts in the minor premise; and whether the specified legal outcome has any effect.

For example, within the Islamic Law, the syllogism goes as described in the below explanation:

a. Major premise- Every legal research in Malaysia apply analysis of states regulation

b. Minor premise- Enactments is a state regulation.

c. Conclusion- Analysis of legal research in Malaysia involves states enactments. 
N.A. Ghazali, I. Sipan \& F.N. Abas

The Methodological Structure for Legal Research: A Perspective from the Malaysian Land Law and Islamic Law

As the historical research, will examine past events or combinations of events to arrive at an account of what has happened in the past (Banakar and Travers, 2005). Just like the earlier system theory, system theory of Islamic Legal Research also has a few elements to describe the complex entity within the system. By using these methods, researchers are formulating the framework as in Figure 5.

\section{ANALYSIS AND FINDING; ADAPTING SYSTEM THEORY APPROACH IN MALAYSIAN LAND LAW AND ISLAMIC LAW}

The researcher scrutinizes each law, determine the regularities and formulate a theory on abidingness and validity related to the concept of the law according to academia writing, journal, article, government support documents and books. System theory approach formulated based on rules of interpretation in broader generalizations of theories of law. Later, it detects patterns and regularities, formulate some tentative hypotheses (major and minor premises) to explore, and finally ends up developing general conclusions or theories as in Figure 5 (Crossman, 2011). This is a method to evaluate the value of the law to achieve the maqasid al-shariah. The rules of interpretation used in order to find the meaning of the legal communication in an Act, which brought it into effect, (Pacific, 2003; (Van and Hundley, 2001). In Islamic Law, the sources of references are Quran and Sunnah as the guidance in life and it is a duty to believe in these two. When Quran is silent, Sunnah is sought. However, when Sunnah is silent, one shall refer to the cognitive natures of Islamic Law which are:

i. Ijma'- unanimous agreement of the Muslim community (Zahrah, 1959, p.372; Ramli, 1938, p.370),

ii. Qiyas- comparison of the other original case (asl) toward proclaimed or rule/hukm (Kamali, 1998).

iii. Istihsan- bringing the new case to another rule based on a stronger reason, (Kamali 1998).

iv. Istislah is a rules based on public interest (Kamali 1998).

v. Urf is a custom of a community (al- Tarabulsi, 1908).

vi. Juristic Interpretation is the opinions of four scholars leading in four schools of law; Hanafi, Maliki, Syafie and Hanbali.

vii. Fatwa- The Fatwa also is a point of Islamic law given by a recognized religious authority (Osman, 1982).

viii. Judicial decisions which based on obiter dictum (purposive principal) and ratio decindi (binding principal) and jurists opinion which is followed by the judge (Islam, 1998, p. 336).

All the sources are known as interrelated hierarchy in system theory approach. Within Malaysian Land Law, the interrelated hierarchy is stand of Statutes the federal and states regulation which record in Act and Enactments 
(written or unwritten law), Judicial Decision in court cases and Academic Opinion in Journal, Articles, books and source of secondary data. Wholeness of system theory is open to all legal sources either in Local Legislation and Foreign Country Law by using rules of interpretation. The system is also shown the characteristics of openness which it is possible to be improved by public and stakeholder within Interview and Pilot Study. The multidimensionality is refers as the system in open two ways direction to propose new rules based on existing local and foreign laws, Quran and Sunnah leads to Maqasid al-Shariah. Finally, the system is purposefulness which made the product of research is intent to public could be operate by validation of the hypothesis to same or different respondents as in Table 2 and Figure 5.

Table 2: The Expansion and Adaptation of Attributes in System Theory

\begin{tabular}{|c|c|c|c|}
\hline $\begin{array}{l}\text { Pure Science } \\
\text { (biologist) }\end{array}$ & $\begin{array}{l}\text { Sosio- } \\
\text { Legal }\end{array}$ & $\begin{array}{l}\text { Islamic- } \\
\text { Legal }\end{array}$ & $\begin{array}{c}\text { Adaptation in Malaysian Land Law } \\
\text { And Islamic Law }\end{array}$ \\
\hline \multirow{3}{*}{$\begin{array}{l}\text { Complex } \\
\text { Entities }\end{array}$} & \multirow[b]{2}{*}{ Input } & $\begin{array}{l}\text { Cognitive } \\
\text { nature of } \\
\text { system }\end{array}$ & $\begin{array}{l}\text { Communication; Source of Islamic Law, } \\
\text { Land Law }\end{array}$ \\
\hline & & $\begin{array}{l}\text { Interrelated } \\
\text { hierarchy }\end{array}$ & $\begin{array}{l}\text {-Islamic Law: Ijma' Qiyas Istihsan } \\
\text { Istislah Urf Juristic Interpretation, Fatwa, } \\
\text { judicial decisions } \\
\text {-Malaysian Land Law: Statutes, Judicial } \\
\text { Decision, Academic Opinion }\end{array}$ \\
\hline & Throughput & Wholeness & $\begin{array}{l}\text { Local Legislation and Foreign Country } \\
\text { Law by using rules of interpretation }\end{array}$ \\
\hline \multirow{3}{*}{$\begin{array}{l}\text { Mathematical } \\
\text { Models }\end{array}$} & Openness & Openness & Interview Experts and Pilot Study \\
\hline & \multirow[t]{2}{*}{ Outputs } & $\begin{array}{l}\text { Multi- } \\
\text { dimensionality }\end{array}$ & $\begin{array}{l}\text { Proposal of new rules based on existing } \\
\text { local and foreign laws, Quran and } \\
\text { Sunnah and Maqasid al-Shariah }\end{array}$ \\
\hline & & Purposefulness & $\begin{array}{l}\text { Validation of new hypothesis to same or } \\
\text { different respondents }\end{array}$ \\
\hline
\end{tabular}


N.A. Ghazali, I. Sipan \& F.N. Abas

The Methodological Structure for Legal Research: A Perspective from the Malaysian Land Law and Islamic Law

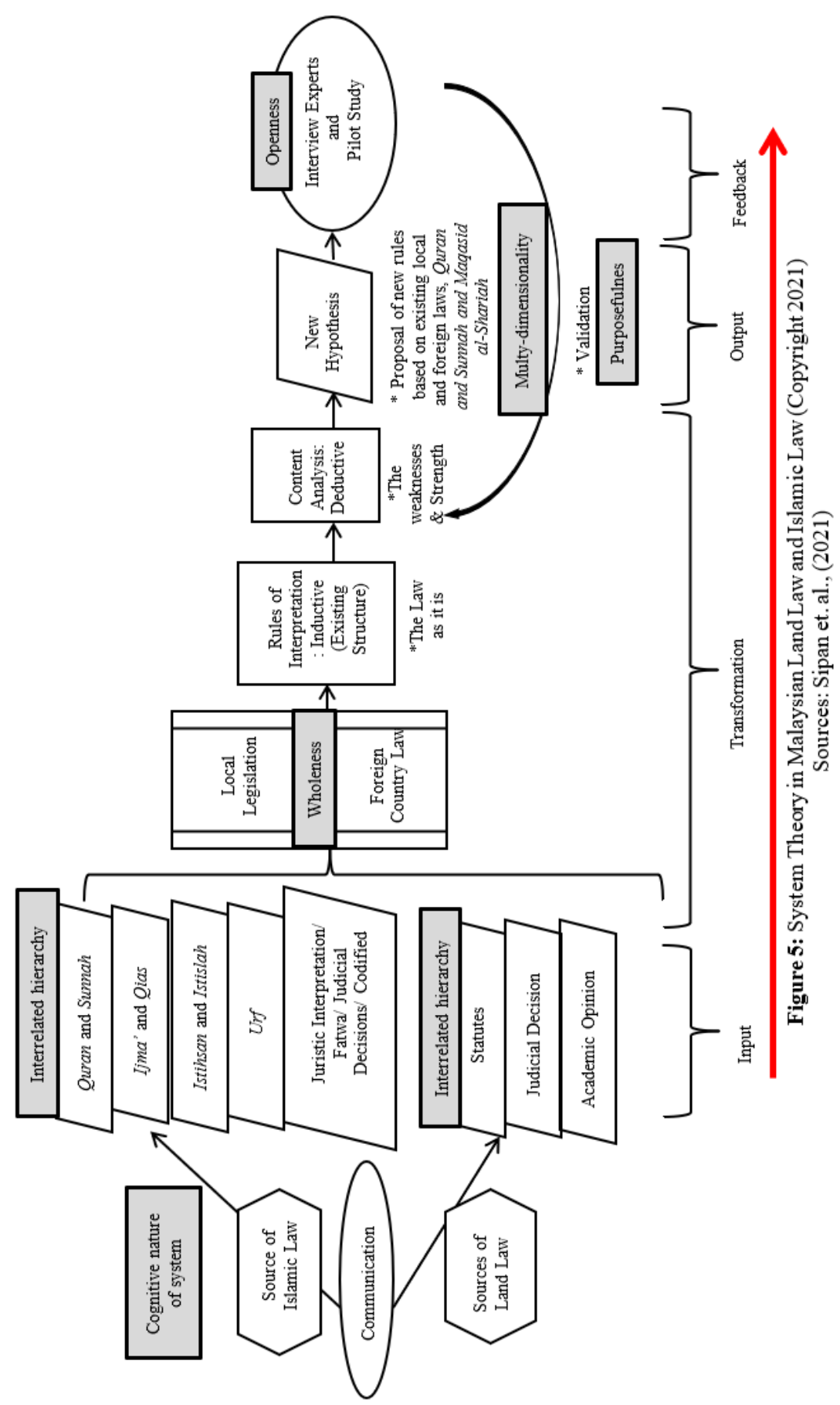




\section{CONCLUSION}

From all theories proposed by researchers in various field of social science, Islamic studies, legislation and jurisdiction, and biology science, this paper is proposing framework as in Figure 5 in order as guide to researchers who adopt Islamic law and civil law in their research. By using the framework, all the essential criteria in Islamic law are taken into consideration to proposed any Syariah compliance model or fundamental theories in the academician studies and practical industries of research and development (R\&D). The limitation of this research is the formulated framework is only verified among the stakeholder and fiqh experts from academicians. This framework shall be taken further research to be exposed among the ulama and Muslim scholars and the fatwa community in order to become one of the best approaches to be adopt by the worldwide ideas. Hopefully, the finding of this paper is managed to contribute in the development planning of regulation which involved Muslim society and multi-racial community in various country.

\section{ACKNOWLEDGEMENT}

This research was supported by Fundamental Research Grant Scheme (FRGS) Phase 1/2019: FRGS/1/2019/SSI10/UTM/02/1, Ministry of Education, Malaysia. We thank our colleagues from Universiti Teknologi Malaysia (vote number: 5 F202) as the supporting institution that provided insight and expertise that greatly assisted the research

\section{REFERENCES}

Afendi, M., \& Sayuti (2012). Implikasi Perundangan Terhadap Pendaftaran Tanah Wakaf Malaysia. Satu Kajian Dari Aspek Akta Pengambilan Tanah. Retrieved from: Http://Www.Scribd.Com/Doc/81330622/Implikasi-Pendaftaran-Tanah-Wakaf

Auda, J. (2008). Maqasid Al-Shariah as Philosophy of Islamic Law. Herndon, USA: The International Institute of Islamic Thought.

Baker, T.L. (1994). Doing Social Research (2nd Edn.). New York: McGraw-Hill Inc

Banakar, R., and Travers, M. (2005). Theory and Method in Sosio-Legal Research, Portland. United State of America: Hart Publishing.

Baur, V. (1965). How to Look up Law and Write Legal Memoranda Revisited. Practical Lawyer, 11, 5 .

Campbell, E. et. al., (1979). Legal Research, Sherwood Court. Perth: the Law Book Company Limited.

Clark, K., and Connolly, M. (2006). A Guide to Reading, Interpreting and Applying Statutes. Notingham, England: Georgetown University Law Center. Retrieved from:

Crankshaft, (2013). Validation (Social Science). What-when-how in Depth Tutorials and Information. Retrieved from: http://what-when-how.com/ socialsciences/validation-social-science 
N.A. Ghazali, I. Sipan \& F.N. Abas

The Methodological Structure for Legal Research: A Perspective from the Malaysian Land Law and Islamic Law

Crossman, A. (2017). An overview to Chaos Theory in Sociology. ThoughtCo. Dotdash Press Publisher. Retrieved from: https://www.thoughtco.com/chaos-theory3026621

Esmaeili, H. (2010). The Relationship between the Waqf Institution in Islamic Law and the Rule of Law in the Middle East. Flinders University, Australia

Farrar, J. H. (1997). Reasoning by Analogy in the Law. Australia: Bond University, p. 9, 30.

Husain, A. (2014). Muslim Personal Law. An Exposition. India, All India Personal Law Board. Camp Office. Retrieved from: http://muslimcanada.org/ muspersonallaw. html\#about

Husain, A. (2014). Muslim Personal Law. An Exposition. India, All India Personal Law Board. Camp Office. Retrieved from: http://muslimcanada.org/ muspersonallaw. html\#about

Ismail W.N.W., Et.Al. (2017) “The Establishment of Islamic Dwelling Principles for The Malaysian Communities”. Planning Malaysia Journal: 15, (1).

Kamali, M.H. (1998). Principles of Islamic Jurisprudence. The Islamic Texts Society. Kuala Lumpur, Malaysia: Ilmiah Pulishers Sdn. Bhd.

Knight, A., and Ruddox, L. (2008). Advance Research Methods In The Built Enviroment. London, UK: Wiley-Blackwell.

Kumar, R. (2019). Research Methodology: A Step-by-Step Guide for Beginners. London, UK: SAGE Publications.

Latip N.S.A., et.al. (2020). The Derivation of Urban Design Principles in Malay-Islamic Town of Kuala Terengganu. Planning Malaysia Journal. 18(2).

Marshal, N.M. (1996). Sampling for qualitative research. Family Practice, 13, 6.

Miles, M.B., and Huberman, M. (1994). Qualitative Data Analysis: An Expanded Sourcebook. 2nd ed. Sydney: SAGE Publication.

Ghazali, N.A., Sipan, I., Haji Mohammad, M.T.S. and Ab Aziz, M.A. (2021), New framework for the management of waqf land registration system in Malaysia, International Journal of Islamic and Middle Eastern Finance and Management, Vol. 14 No. 3, pp. 625-640. DOI: doi.org/10.1108/IMEFM-04-2019-0172

Omar, M.M. (2013). Isu Pentadbiran Tanah Wakaf dalam Konteks KTN 1965 dan Pejabat Tanah dan Galian Negeri Sembilan. Jurnal Pentadbiran Tanah, 25-37.

Osman, A. Z. (2012). Accountability in managing waqf properties: the case of two State Religious Councils in Malaysia. London: School of Management, Royal Holloway University. $348 . \quad$ Retrieved from: https:/ethos.bl.uk/ OrderDetails.do?uin=uk.bl.ethos.553846

Pacific, U.O.S. (2003). Principles Relating to the Interpretation of Statutes and Constitutions. Port Vila, Vanuatu: PacLII.

Polit, D.F., Beck, C.T., and Hungler, B.P. (2001). Essentials of Nursing Research: Methods, Appraisal and Utilization. 5th Ed., Philadelphia: Lippincott Williams \& Wilkins

Ramli, M.I.A. (1938). Nihayat al-Muhtaj, Cairo: Open source. 368

Sarkawi, A.A., Ibrahim, A.B., \& Abdullah, A. (2008). The Contribution of Fiqh AlJinayat (Islamic Criminal Law) In the Planning of a Safe City, Planning Malaysia Journal. 6 (1). 
Sipan, I., et.al., (2021). Johor: UTM Innovation and Commercialisation Centre (ICC). Copyright 2021by Universiti Teknologi Malaysia. Reprinted [or adapted] with permission.

Tobi, U. (2013). Research Methodological Cage. Kuala Lumpur, Malaysia: Aras Publisher.

Twente, T.U.O. (1960). System Theory. Communication Theories. Netherlands: University of Twente.

University, T.O. (2014). Judges and the law. United Kingdom: LabSpace.

Van Teijlingen, E. R., and Hundley, V. (2001). The importance of pilot studies. Social Research Update, (35).

Wyse, S. E. (2011). Difference between Qualitative Research and Quantitative Research, Research Gate.

Zahrah, A. (1959). Muhadarat fi-al-waqf (lectures on waqf). Cairo: Matba'ah Ahmad 'Ali Mukhaimar. 48

Received: $12^{\text {th }}$ July 2021 . Accepted: $17^{\text {th }}$ Sept 2021 